\title{
SENSITIVITY OF AN IMMUNOENZYMATIC TEST FOR THE DETECTION OF ANTI-L. braziliensis ANTIBODIES COMPARED TO OTHER TESTS USED FOR THE DIAGNOSIS OF AMERICAN CUTANEOUS LEISHMANIASIS
}

\author{
Maíra Peres FERREIRA(1), Ana Maria Ferreira ROSElinO(2), Margarida Maria Passeri NASCIMENTO(1), Juliana Machado AIRES(2)
}

\& José Fernando de Castro FIGUEIREDO(1)

\begin{abstract}
SUMMARY
The diagnosis of American cutaneous leishmaniasis (ACL) is frequently based on clinical and epidemiological data associated with the results of laboratory tests. Some laboratory methods are currently being applied for the diagnosis of ACL, among them the indirect immunofluorescence reaction (IIFR), the Montenegro skin test (MST), histopathological examination, and the polymerase chain reaction (PCR). The performance of these methods varies in a considerable proportion of patients. After the standardization of an immunoenzymatic test (ELISA) for the detection of IgG in the serum of patients with ACL using a crude Leishmania braziliensis antigen, the results obtained were compared to those of other tests routinely used for the diagnosis. The tests revealed the following sensitivity, when analyzed separately: $85 \%$ for ELISA IgG, $81 \%$ for PCR, $64.4 \%$ for MST, 58.1\% for IIFR, and 34\% for the presence of parasites in the biopsy. ELISA was positive in $75 \%$ of patients with ACL presenting a negative MST, in $84.8 \%$ of ACL patients with negative skin or mucous biopsies for the presence of the parasite, and in 100\% of cases with a negative PCR. Thus, ELISA presented a higher sensitivity than the other tests and was useful as a complementary method for the diagnosis of ACL.
\end{abstract}

KEYWORDS: American cutaneous leishmaniasis; Diagnosis; Immunoenzymatic assay; Leishmania braziliensis.

\section{INTRODUCTION}

The leishmaniasis are among the most frequent infectious-parasitic diseases in the world, with an estimated world prevalence of 12 million patients and an incidence of about 600,000 new cases per year ${ }^{4,10}$. Over the last few years, the occurrence of American cutaneous leishmaniasis (ACL) has been increasing in the Northeast region of the state of São Paulo and neighboring states. In some regions such as the Vale do Ribeira, Campinas and Sorocaba, epidemic outbreaks have been reported, usually linked to soil occupation by new planting areas or to invasion of the forest by urban expansion ${ }^{2}$.

A definitive diagnosis of ACL is frequently based on clinical and epidemiologic data associated with a laboratory diagnosis. The tests traditionally used for the diagnosis of this disease are the indirect immunofluorescence reaction (IIFR), the Montenegro skin test (MST), histopathological examination, and the polymerase chain reaction (PCR). The standardization of an immunoenzymatic test (ELISA) as an aid for the diagnosis of ATL is justified since these routinely applied tests have variable sensitivity.

The objective of the present study was to compare the sensitivity of an ELISA test using a Leishmania (V.) braziliensis strain as antigen to the sensitivity of IIFR, MST and PCR in a skin or mucosa biopsy and to the visualization of parasites in a skin or mucosa biopsy from patients with ACL attended at the University Hospital of the Faculty of Medicine of Ribeirão Preto, University of São Paulo.

\section{PATIENTS AND METHODS}

The study was approved by the Research Ethics Committee of HCFMRP/USP (Process HCRP No. 3308/2003) and all subjects gave written informed consent to participate.

Patients. The study was conducted in the serum of 53 patients attended at the Infectious Diseases and Dermatology outpatient clinics of HCFMRP/USP with signs and symptoms compatible with ACL, associated with positivity to at least one of the following tests: IIFR for leishmaniasis (titers $\geq 1: 40$ ). MST (presence of a papule or nodule $\geq 5 \mathrm{~mm}$ in diameter), PCR (using specific primers) in skin or mucous biopsy, and visualization of the parasites in a skin or mucous biopsy.

The data regarding the results of the tests that were compared to ELISA were obtained by reviewing the medical records of the patients. 


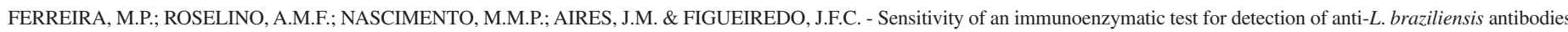
compared to other tests used for the diagnosis of American cutaneous leishmaniasis. Rev. Inst. Med. trop. S. Paulo, 48(4): 215-217, 2006.

Immunoenzymatic assay. Leishmania braziliensis promastigotes (strain 2762) were kept in Schnneider's Drosophila liquid medium" $(\text { Gibco })^{3}$ supplemented with $2 \%$ male urine, $20 \%$ sterile fetal calf serum and $1 \%$ gentamicin. The parasite pellet, obtained after centrifugation of the culture medium, was suspended in $0.5 \mathrm{~mL}$ sterile distilled water and submitted to at least 12 cycles of freezing and thawing using liquid nitrogen and a water bath at $70{ }^{\circ} \mathrm{C}$. After the last cycle, the tubes were centrifuged and the supernatant containing the antigen preparation was removed for the quantitation of protein content ${ }^{6}$. The antigen thus obtained was stored in a freezer at $-70{ }^{\circ} \mathrm{C}$ in $1 \mathrm{~mL}$ aliquots until the time for use.

A noncompetitive indirect immunoassay method (ELISA) ${ }^{11}$ was applied using polystyrene microtiter plates as the solid phase (Immulon II - Dynatech Laboratories) and peroxidase-conjugated goat anti-human IgG (Sigma Immuno Chemicals). Hydrogen peroxide $\left(\mathrm{H}_{2} \mathrm{O}_{2}\right)$ and ophenylenediamine di-hydrochloride (Sigma) were used as substrate. The results were reported as the OD/cut-off ratio, with values $\geq 1$ being considered positive.

\section{RESULTS}

The sensitivity of the different diagnostic tests applied to patients with ACL was analyzed separately and was found to be $85 \%$ for the ELISA anti-IgG test in serum, $81 \%$ for PCR in a skin or mucous biopsy, $64.4 \%$ for MST, $58.1 \%$ for IIFR for leishmaniasis, and $34 \%$ for the presence of parasites in the biopsy. These values are illustrated in Fig. 1.

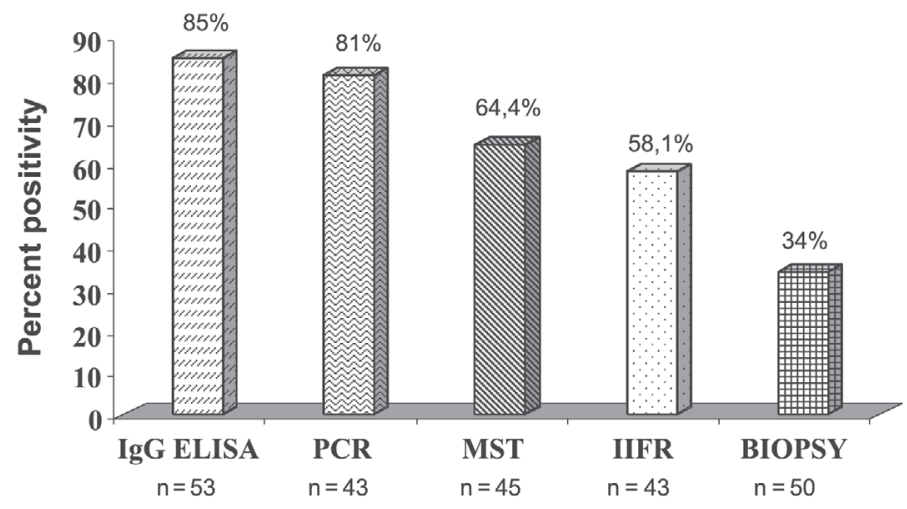

Fig. 1 - Sensitivity of each test when used separately in patients with ACL.

The performance of ELISA compared to the results obtained with the MST, with the visualization of parasites in a skin and/or mucous biopsy and with PCR applied to a skin and/or mucous biopsy can be observed in Fig. 2, 3 and 4.

It can be seen that ELISA was positive in $75 \%$ of ATL patients with a negative MST (Fig. 2). Similarly, the test was positive in $84.8 \%$ of ATL patients with a skin or mucosa biopsy that was negative for the presence of parasites (Fig. 3) and detected $100 \%$ of cases with a negative PCR applied to a skin or mucous biopsy (Fig. 4).

\section{DISCUSSION}

The usefulness of ELISA as an alternative method for the diagnosis of ACL, was evident since the performance of the test was superior to

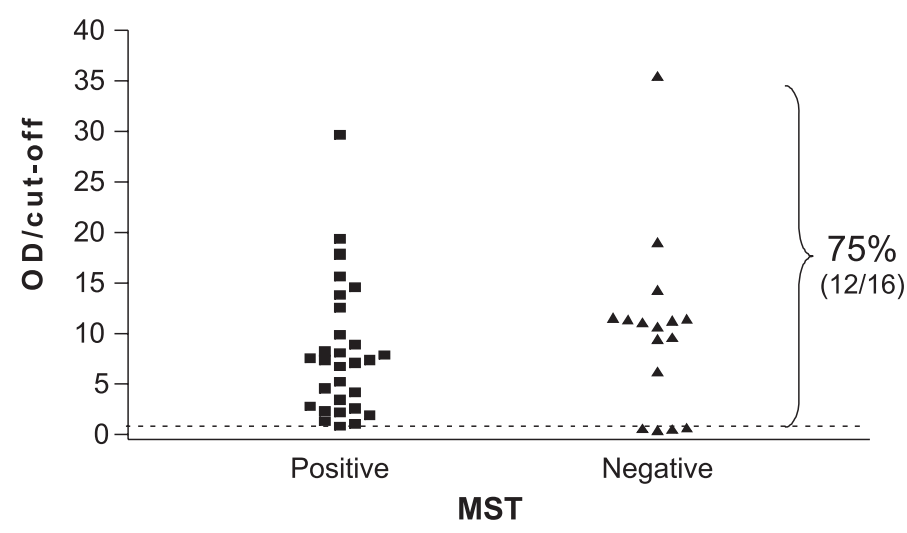

Fig. 2 - Values of OD/cut-off of ELISA for the detection of anti-L.braziliensis IgG in the serum of patients with ACL according to the result of the Montenegro intradermal reaction. Dotted horizontal line: cut-off $=1.0$.

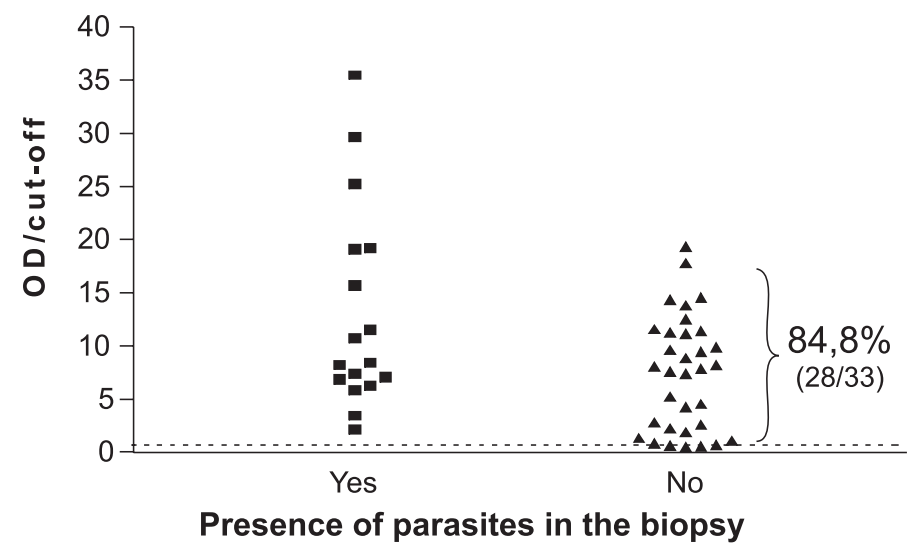

Fig. 3 - Values of OD/cut-off of ELISA for the detection of anti-L.braziliensis IgG in the serum of patients with ACL according to the presence of the parasite in the biopsy. Dotted horizontal line: cut-off $=1.0$.

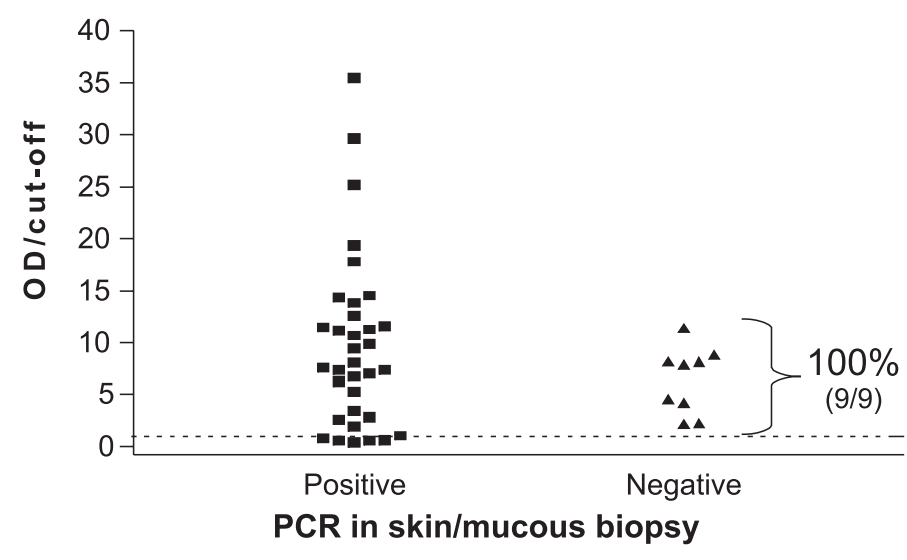

Fig. 4 - Values of OD/cut-off of ELISA for the detection of anti-L.braziliensis IgG in the serum of patients with ACL according to the result of the polymerase chain reaction. Dotted horizontal line: cut-off $=1.0$. 
that of all the other diagnostic tests used. GARCIA ${ }^{4}$ detected positivities similar to those reported here but did not report about ELISA. He observed $81.6 \%$ positivity for PCR, $73.4 \%$ for MST, $59.7 \%$ for IIFR, and $30.6 \%$ for a biopsy. ODDONE et al. $^{8}$, in a study of the usefulness of diagnostic tests applied to mucous leishmaniasis, detected $100 \%$ positivity for MST, $88 \%$ for PCR, $78.6 \%$ for IIFR, $16 \%$ for parasite culture, and $4 \%$ for histopathology, but did not use ELISA. In the evaluation of ELISA using an L. tropica major antigen in patients with cutaneous leishmaniasis caused by this parasite, ROFFI et al. ${ }^{9}$ reported 97\% positivity for the test. The Health Ministry ${ }^{7}$ estimates $90 \%$ positivity for MST and $70 \%$ for IIFR in ulcerated lesions caused by $L$. (V). braziliensis. On the other hand, PCR is not recommended in this publication as a standardized method for the laboratory diagnosis of ACL. GONTIJO \& CARVALHO ${ }^{5}$ consider culture to have $50 \%$ overall sensitivity for L. braziliensis infections. In contrast, the micro-ELISA test showed $100 \%$ positivity in patients with a confirmed diagnosis of cutaneous leishmaniasis with the presence of multiple lesions and in patients with cutaneous-mucosal leishmaniasis when promastigote forms of L. braziliensis panamensis were used ${ }^{1}$.

Thus, the ELISA test presented higher sensitivity in the population studied compared separately to the other tests and can be considered a complementary method for the diagnosis of ACL because it identified a considerable proportion of patients with ACL who presented negative results in the other diagnostic tests.

\section{RESUMO}

Sensibilidade de teste imunoenzimático anti-L. braziliensis em relação a outros testes utilizados no diagnóstico da leishmaniose tegumentar americana

O diagnóstico da Leishmaniose Tegumentar Americana (LTA) é feito com base nos dados clínicos e epidemiológicos e é confirmado por meio de diferentes métodos laboratoriais. Dentre estes, são utilizados, com desempenhos variáveis, a reação de imunofluorescência indireta (IFI), a reação intradérmica de Montenegro (IRM), a pesquisa de Leishmania em material de biópsia de pele ou mucosa e a reação em cadeia da polimerase (PCR). O objetivo do presente trabalho foi avaliar o desempenho de teste imunoenzimático (ELISA) como método alternativo de diagnóstico da LTA, comparando seus resultados com os obtidos por outros métodos tradicionais de diagnóstico dessa doença. Foi utilizado teste para pesquisa de IgG anti-Leishmania no soro, utilizando antígeno bruto de Leishmania braziliensis, com os seguintes resultados de sensibilidade: ELISA $=85 \% ; \mathrm{PCR}=81 \% ; \mathrm{IRM}=64.4 \%$;
IFI $=58,1 \%$; presença de parasitas na biópsia $=34 \%$. Além disso, o teste ELISA foi positivo em parcela expressiva dos pacientes que apresentavam outros testes diagnósticos negativos (foi positivo em $100 \%$ dos pacientes com PCR negativo; em $84,8 \%$ dos casos com biópsias mostrando ausência de parasitas e em $75 \%$ dos não reativos a IRM) mostrando-se útil como método alternativo de diagnóstico da LTA.

\section{REFERENCES}

1. ANTHONY, R.L.; CHRISTENSEN, H.A. \& JOHNSON, C.M. - Micro enzyme-linked immunosorbent assay (ELISA) for the serodiagnosis of New World Leishmaniasis. Amer. J. trop. Med. Hyg., 29: 190-194, 1980.

2. CAMARGO-NEVES, V.L.F. \& BRASIL, M.T.L.R.F. - Leishmaniose tegumentar americana no Estado de São Paulo: situação epidemiológica 2001-2002. Rev. Soc. bras. Med. trop., 36 (supl. 2): 30-35, 2003.

3. CHILDS, G.E.; FOSTER, K.A. \& McROBERTS, M.J. - Insect cell culture media for cultivation of New World Leishmania. Int. J. Parasit., 8: 255-258, 1978.

4. GARCIA, F.C.B. - Métodos subsidiários para o diagnóstico da ATL: comparação dos resultados do sequenciamento de DNA e da PCR-RFLP para determinação da espécie de Leishmania em amostras cutâneo-mucosas (janeiro de 1993 a junho de 2004). Ribeirão Preto, 2005. (Dissertação de Mestrado - Faculdade de Medicina de Ribeirão Preto da Universidade de São Paulo).

5. GONTIJO, B. \& CARVALHO, M.L.R. - Leishmaniose tegumentar americana. Rev. Soc. bras. Med. trop., 36: 71-80, 2003.

6. LOWRY, O.H.; ROSEBROUGH, N.J.; FARR, A.L. \& RANDALL, R.J. - Protein measurement with the Folin phenol reagent. J. biol. Chem., 193: 265-275, 1951.

7. MINISTÉRIO DA SAÚDE. BRASIL - Vigilância epidemiológica: manual de controle da leishmaniose tegumentar americana. Brasília, FUNASA, 2000.

8. ODDONE, R.; ARBO, C.; NARA, E. et al. - Utilidad diagnóstica de los métodos laboratoriales en leishmaniasis mucosa, incluyndo la "PCR". Noticias Técnicas del Laboratorio, 4: 7, 2004.

9. ROFFI, J.; DEDET, J.P.; DESJEUX, P. \& GARRÉ, M.T. - Detection of circulating antibodies in cutaneous leishmaniasis by enzyme-linked immunosorbent assay (ELISA). Amer. J. trop. Med. Hyg., 29: 183-189, 1980.

10. SAMPAIO, S.A.P. \& RIVITTI, E.A. - Leishmaniose e outras dermatoses por protozoários. In: SAMPAIO, S.A.P. Dermatologia. São Paulo, Artes Médicas, 1998. p. 565-574.

11. VOLLER, A.; DRAPER, C.; BIDWELL, D.E. \& BARTLETT, A. - Microplate enzymelinked immunosorbent assay for Chagas' disease. Lancet, 1: 426-428, 1975.

Received: 14 December 2005

Accepted: 22 March 2006 